\title{
Perbandingan kepekaan pola kuman ulkus diabetik terhadap pemakaian PHMB gel dan $\mathrm{NaCl}$ gel secara klinis
}

\author{
${ }^{1}$ Sendi Kurnia, ${ }^{2}$ Richard Sumangkut, ${ }^{2}$ Mendy Hatibie \\ ${ }^{1}$ Program Studi Ilmu Bedah Fakultas Kedokteran Universitas Sam Ratulangi Manado \\ ${ }^{2}$ KSM Ilmu Bedah RSUP Prof. Dr. R. D. Kandou Manado \\ Email: sendi_kt@yahoo.com
}

\begin{abstract}
The prevalence of diabetes mellitus (DM) is increased globally every year, especially in developed countries. In Indonesia, the prevalence of diabetic ulcers is amounted to $15 \%$. Mortality and amputation are as high as $32.5 \%$ and $23.5 \%$ and are the most common cause of diabetic patient care in the hospital. This study was aimed to compare the sensitivity of diabetic ulcers' bacteria to PHMB gel with $0.9 \%$ saline gel. This was a descriptive analytical study. Subjects were 57 patients of diabetic ulcer associated with infection. Pus samples obtained from the diabetic ulcers were cultured and were further evaluated for the sensitivity test to PHMB gel and saline gel. Data were analyzed by using the $z$ test. The results showed that the proportion of bacteria' sensitivity to PHMB was significantly different $(P<0.05)$ meanwhile to $20 \%$ saline gel was not significantly different $(P<0.05)$. Conclusion: Application of PHMB gel could improve the process of wound healing of diabetic ulcer with infection.
\end{abstract}

Keywords: PHMB gel, $\mathrm{Na} \mathrm{Cl}$ gel, diabetic ulcer with infection

\begin{abstract}
Abstrak: Prevalensi penyandang diabetes melitus (DM) secara global semakin meningkat setiap tahunnya terutama di negara berkembang. Di Indonesia, prevalensi ulkus diabetik pada penyandang DM sebesar $15 \%$. Angka kematian dan amputasi sangat tinggi yaitu sebesar 32,5\% dan 23,5\% yang merupakan penyebab terbanyak perawatan di rumah sakit. Penelitian ini bertujuan untuk mendapatkan pola kuman pada ulkus diabetik serta membandingkan kepekaan kuman terhadap PHMB gel dan $\mathrm{NaCl}$ gel. Jenis penelitian ialah deskriptif analitik. Subyek penelitian ialah 57 pasien dengan ulkus diabetik disertai infeksi. Sampel pus dari ulkus diabetik dibuat kultur kemudian dilanjutkan dengan uji kepekaan kuman terhadap PHMB gel dan $\mathrm{NaCl}$ gel. Data dianalisis menggunakan uji $z$. Hasil uji statistik mendapatkan perbedaan proporsi kepekaan kuman terhadap PHMB yang bermakna $(P<0,05)$ sedangkan perbedaan proporsi kepekaan kuman terhadap $\mathrm{NaCl}$ gel $20 \%$ tidak bermakna $(P>0,05)$. Simpulan: Pemberian PHMB gel dapat meningkatkan proses penyembuhan luka pada penyandang DM dengan ulkus yang disertai infeksi.
\end{abstract}

Kata kunci: $\mathrm{PHMB}$ gel, $\mathrm{Na} \mathrm{Cl}$ gel, ulkus diabetik dengan infeksi

Prevalensi penyandang diabetes melitus (DM) secara global semakin meningkat setiap tahunnya terutama di negara berkembang. Tahun 2000 prevalensi penyandang DM di dunia ialah $2,8 \%$ atau 171 juta jiwa. Jumlah ini meningkat menjadi $6,6 \%$ atau 285 juta jiwa di tahun 2010; 80\% penyandang DM berdiam di negara berkembang. ${ }^{1,2}$ Di Indonesia pada tahun 2003 prevalensi penyandang DM sebesar 1,5-2,3\%, dan angka ini meningkat menjadi 5,7\% pada tahun 2008 dengan daerah urban memiliki angka tertinggi yaitu 14,7\%. Angka ini meningkat 2-3 kali dibandingkan dengan negara maju. ${ }^{3}$ Keadaan ini disebabkan antara lain oleh harapan hidup yang lebih lama, gaya hidup sedentary, dan perubahan pola makan 
penduduk. $^{1-3}$ Hal ini membutuhkan perhatian semua pihak karena penyakit DM memberikan komplikasi makrovaskuler maupun mikrovaskuler yang sangat merugikan bagi penyandang DM, keluarga, maupun negara. ${ }^{2}$

Penyembuhan luka merupakan proses yang kompleks dan dinamis. Pada saat luka mulai menyembuh biasanya proses penyembuhan komplit akan tercapai. Walaupun demikian proses penyembuhan tidak hanya terbatas pada proses regenerasi yang bersifat lokal, tetapi juga sangat dipengaruhi oleh berbagai faktor endogen, antara lain: usia, nutrisi, sistem imun, pemakaian obat-obatan, dan kondisi metabolik. Penyembuhan luka yang dimulai dari suatu penyembuhan yang terganggu akan tidak mudah karena standar perawatan luka biasa seringkali tidak menunjukkan perkembangan dan sering membutuhkan terapi tambahan. ${ }^{3}$

Ulkus diabetik merupakan komplikasi menahun yang paling ditakuti dan mengesalkan bagi pasien DM. Hal ini disebabkan oleh waktu perawatan lama, biaya pengobatan tinggi, serta bahaya amputasi yang dapat menimbulkan kecacatan hingga kematian. ${ }^{4,5}$ Sejak tahun 2005 International Diabetes Federation (IDF) memfokuskan kampanye penanganan dini dan pencegahan terjadinya amputasi pada penderita ulkus diabetik. ${ }^{5}$

Prevalensi penderita ulkus diabetik pada penyandang DM di dunia berkisar 410\%. Terdapat $40-70 \%$ kasus amputasi non-trauma, dan $85 \%$ kasus amputasi ialah pada penyandang DM. Penyebab amputasi ialah faktor iskemik $50-70 \%$ dan infeksi $30-50 \%$. Biaya perawatan seorang penderita selama setahun sebesar US\$ 13,179-23,372 dan total biaya perawatan di Amerika Serikat pada tahun 2007 sebesar US\$ 30,6 miliar. $^{2}$

Prevalensi ulkus diabetik pada penyandang DM di Indonesia dilaporkan sebesar 15\%. Angka kematian dan amputasi sangat tinggi yaitu sebesar 32,5\% dan $23,5 \%$ serta merupakan penyebab terbanyak perawatan penyandang DM di rumah sakit yaitu sebesar $80 \%$ dengan besaran biaya perawatan seorang pasien berkisar Rp 1,3-1,6 juta perbulan dan Rp 43,5 juta per tahun. ${ }^{6}$

Pengobatan infeksi pada ulkus diabetik harus dilakukan secara rasional, bersama baik sistemik maupun lokal pada daerah ulkus atau gangren dengan menggunakan antibiotika yang sesuai dengan hasil kultur dan uji kepekaan pada kuman atau pola kuman penderita ulkus diabetik. ${ }^{7-9}$ Perawatan ulkus diabetik terinfeksi membutuhkan biaya besar, waktu perawatan lama, dan melibatkan tenaga ahli dari beberapa disiplin ilmu masih menjadi kendala bagi masyarakat Indonesia sehingga penderita sering membiarkan ulkus terinfeksi tanpa perawatan yang baik. $^{8}$

Salah satu pengobatan topikal yang dapat digunakan untuk ulkus diabetik ialah antiseptik polyhexamethylene biguanide (PHMB) yaitu senyawa sintetik dengan struktur kimia yang sama dengan antimikroba peptida (AMP) alamiah pada keratinosit dan neutrofil. AMP memiliki spektrum yang luas terhadap aktivitas bakteri, virus, dan jamur serta menginduksi kematian sel dengan mengganggu integritas membran sel. ${ }^{10}$

$\mathrm{NaCl}$ gel terdiri dari air, $\mathrm{NaCl} 0,9 \%$ dan bahan gelatin viskositas maksimum 100.000 cps. $\mathrm{NaCl}$ gel dapat memromosi autolitik debrideman secara cepat namun lembut dengan melonggarkan dan mengabsorbsi jaringan nekrotik dan eksudat luka; juga digunakan untuk menyediakan lingkungan lembab yang diperlukan pada setiap fase penyembuhan luka. Pemakaian $\mathrm{NaCl}$ gel bersifat non adhesif dan tidak merusak jaringan ikat pada luka yang masih viable. ${ }^{11}$

Penelitian ini bertujuan untuk membandingkan kepekaan pola kuman pada ulkus diabetik antara pemakaian PHMB gel dan $\mathrm{NaCl}$ gel. Dengan mengetahui pola kuman yang dilanjutkan dengan menguji kepekaan kuman diharapkan mendapatkan senyawa yang efektif untuk mengurangi mikroba pada penderita ulkus diabetik, efisien, aman (tidak toksik/merusak jaringan kulit), 
murah, dan mudah diperoleh.

\section{METODE PENELITIAN}

Jenis penelitian ini ialah diskriptif analitik. Penelitian dilakukan di Bagian Bedah Fakultas Kedokteran Universitas Sam Ratulangi/RSUP Prof. Dr. R. D. Kandou Manado bekerjasama dengan Poliklinik Subdivisi Endokrinologi Bagian Penyakit Dalam, Labotorium Mikrobiologi Fakultas Kedokteran Universitas Sam Ratulangi, dan RSUP Prof. Dr. R. D. Kandou Manado. Penelitian dimulai pada bulan Januari sampai dengan Maret 2016. Subyek penelitian ialah penyandang DM dengan komplikasi ulkus diabetik terinfeksi. Sampel kuman diambil dari pus ulkus diabetik kemudian dibuat kultur. Pola kuman diperoleh dari hasil kultur kuman yang selanjutnya dilakukan uji kepekaan terhadap PHMB gel dan $\mathrm{NaCl}$ gel; setelah 24 jam dievaluasi zona hambat kuman yang terbentuk.

\section{HASIL PENELITIAN}

Pada penelitian ini didapatkan 57 pasien yang memenuhi kriteria inklusi. Tabel 1 memperlihatkan hasil kultur dari pus penderita ulkus diabetik dan pola kuman yang terbanyak ialah kuman Proteus mirabilis sebanyak 14 pasien $(24,6 \%)$ yang bersifat Gram negatif.

Tabel 2 memperlihatkan hasil uji kepekaan kuman. PHMB gel menunjukkan kepekaan $100 \%$ dari 8 jenis kuman, kepekaan 50\% dari kuman Proteus vulgaris sedangkan $\mathrm{NaCl}$ gel menunjukkan hasil resistensi dari seluruh pola kuman.

Tabel 1. Pola kuman ulkus diabetik

\begin{tabular}{clcc}
\hline No & \multicolumn{1}{c}{ Jenis kuman } & Jumlah & \% \\
\hline $\mathbf{1}$ & Proteus mirabilis & 14 & 24,6 \\
$\mathbf{2}$ & Pseudomonas aeroginosa & 5 & 8,8 \\
$\mathbf{3}$ & Citrobacter diversus & 4 & 7,0 \\
$\mathbf{4}$ & Enterobacter aerogenes & 4 & 7,0 \\
$\mathbf{5}$ & Staphylococcus aureus & 3 & 5,3 \\
$\mathbf{6}$ & Klebsiela pneumonia & 3 & 5,3 \\
$\mathbf{7}$ & Staphylococcus epidermidis & 6 & 10,5 \\
$\mathbf{8}$ & Streptococus sp & 4 & 7,0 \\
$\mathbf{9}$ & Eschericia coli & 10 & 17,5 \\
$\mathbf{1 0}$ & Proteus Vulgaris & 4 & 7,0 \\
& Total & 57 & 100 \\
\hline
\end{tabular}

Tabel 2. Hasil uji perbedaan proporsi kepekaan pola kuman pada ulkus diabetik terhadap PHMB gel dan $\mathrm{NaCl}$ gel

\begin{tabular}{clccc}
\hline \multirow{2}{*}{ No } & \multicolumn{1}{c}{ Jenis kuman } & \multicolumn{2}{c}{ Sensitivitas } & \multirow{2}{*}{ Kemaknaan } \\
\cline { 3 - 4 } & & PHMB gel & NaCl Gel & \\
\hline $\mathbf{1}$ & Proteus mirabilis & 14 & 0 & $P=0,0001$ \\
$\mathbf{2}$ & Pseudomonas aeroginosa & 5 & 0 & $P=0,011$ \\
$\mathbf{3}$ & Citrobacter diversus & 4 & 0 & $P=0,021$ \\
$\mathbf{4}$ & Enterobacter aerogenes & 4 & 0 & $P=0,021$ \\
$\mathbf{5}$ & Staphylococcus aureus & 2 & 0 & $P=0,077$ \\
$\mathbf{6}$ & Klebsiela pneumonia & 3 & 0 & $P=0,040$ \\
$\mathbf{7}$ & Staphylococcus epidirmidis & 6 & 0 & $P=0,006$ \\
$\mathbf{8}$ & Streptococcus sp & 4 & 0 & $P=0,021$ \\
$\mathbf{9}$ & Eschericia coli & 10 & 1 & $P=0,002$ \\
$\mathbf{1 0}$ & Proteus Vulgaris & 2 & 0 & $P=0,077$ \\
\hline
\end{tabular}


Uji chi square untuk perbedaan proporsi kepekaan antara PHMB gel dan $\mathrm{NaCl}$ gel terhadap pola kuman ulkus diabetika mendapatkan $P \quad<0,05$ pada kuman Proteus mirabilis, Pseudomonas aeroginosa, Citrobacter diversus, Staphylococcus epidermidis, Klebsiela Pneumonia, Streptococcus sp dan Escherichia coli yang menunjukkan terdapat perbedaan bermakna antara pemakaian $\mathrm{PHMB}$ gel dan $\mathrm{NaCl}$ gel sedangkan pada kuman Proteus vulgaris dan Stapyhlococcus aureus didapatkan $P$ $>0,05$ yang menunjukkan tidak didapat perbedaan bermakna antara pemakaian PHMB gel dan $\mathrm{NaCl}$ gel. Hasil uji chi square untuk perbedaan proporsi resistensi antara PHMB gel dan $\mathrm{NaCl}$ gel terhadap pola kuman ulkus diabetik mendapatkan perbedaan yang tidak bermakna $(P>0,05)$ pada kuman Staphylococcus aureus dan Proteus vulgaris.

Tabel 3. Hasil uji perbedaan proporsi resistensi pola kuman ulkus diabetic terhadap PHMB gel dan $\mathrm{NaCl}$ gel

\begin{tabular}{|c|c|c|c|c|}
\hline \multirow[t]{2}{*}{ No } & \multirow[t]{2}{*}{ Jenis kuman } & \multicolumn{2}{|c|}{ Resistensi } & \multirow[t]{2}{*}{ Kemaknaan } \\
\hline & & PHMB GEL & $\mathrm{NaCl} \mathrm{Gel}$ & \\
\hline 1 & Proteus mirabilis & 0 & 14 & $P=0,0001$ \\
\hline 2 & Pseudomonas aeroginosa & 0 & 5 & $P=0,011$ \\
\hline 3 & Citrobacter diversus & 0 & 4 & $P=0,021$ \\
\hline 4 & Enterobacter aerogenes & 0 & 4 & $P=0,021$ \\
\hline 5 & Staphylococcus aureus & 1 & 3 & $P=0,154$ \\
\hline 6 & Klebsiela pneumonia & 0 & 3 & $P=0,040$ \\
\hline 7 & Staphylococcus epidermidis & 0 & 6 & $P=0,006$ \\
\hline 8 & Streptococcus sp & 0 & 4 & $P=0,021$ \\
\hline 9 & Eschericia coli & 0 & 9 & $P=0,002$ \\
\hline 10 & Proteus Vulgaris & 2 & 4 & $P=0,201$ \\
\hline
\end{tabular}

\section{BAHASAN}

Diabetes melitus merupakan penyakit kronis progresif yang menjadi salah satu permasalahan medis, bukan hanya karena prevalensinya yang meningkat dari tahun ke tahun, tetapi juga karena penyakit ini umumnya dapat bermanifestasi ke gangguan penyakit sistemik lain seperti kelainan makro dan mikrovaskuler. Invasi jaringan kulit oleh mikroorganisme yang awalnya fisiologik dapat menjadi patogen pada ulkus diabetik disebabkan oleh faktor iskemik, neuroiskemik, maupun neuropati, diikuti oleh respon inflamasi lokal maupun sistemik yang disertai adanya kolonisasi bakteri. $^{12}$

PHMB sebagai basa kuat mempunyai sifat bakterisidal, berikatan dengan fosfat bermuatan negatif pada membran fosfolipid bakteri, menghancurkan membran luar dan dalam dari dinding sel bakteri melalui gangguan permeabilitas dan mengeluarkan sitoplasma sel bakteri dengan cara osmosis sehingga sel bakteri mengalami kematian. ${ }^{13,14} \mathrm{NaCl}$ berbentuk cair sebagai bakterisidal, bekerja dengan cara mendilusi dan menghancurkan membran luar dari bakteri, dan setelah membran tersebut hancur, elektrolisis dari $\mathrm{NaCl}$ menghasilkan klorin bebas, seperti $\mathrm{HCLO}, \mathrm{Cl}_{2}$ dan $\mathrm{Cl}^{-}$. Klorin ini akan berinteraksi dengan enzim bakteri dan menghancurkan periplasma dan membran dalam sehingga sitoplasma dapat keluar dari sel bakteri yang berakibat kematian sel bakteri. ${ }^{15,16}$

Dari 57 subyek penelitian didapatkan hasil kuman Gram negatif dengan persentase tertinggi $(77,2 \%)$. Hal ini sesuai dengan acuan pustaka yang menyatakan bahwa kuman Gram negatif sering ditemukan pada keadaan infeksi berat yang disertai adanya jaringan nekrotik atau gangren. Kuman patogen terbanyak yang ditemukan pada ulkus diabetik ialah Proteus 
mirabilis, Eschericia coli, Staphylococcus epidermidis, Pseudomonas aeroginosa, Citrobacter diversus, Enterobacter aerogenes, dan Staphylococcus sp. Proteus mirabilis, Pseudomonas aeroginosa, Citrobacter diversus, dan Enterobacter aerogenes yang merupakan kuman Gram negatif, sedangkan Staphylococcus epidermidis dan Staphylococcus sp. merupakan kuman Gram positif. Hal ini sesuai dengan acuan pustaka yang menyatakan bahwa infeksi pada ulkus diabetik bersifat polibakteri. Dari beberapa hasil percobaan kultur pus terinfeksi ditemukan 4,1-5,8 jenis kuman dalam satu sampel lapangan infeksi. ${ }^{9,17,18}$

Pada penelitian ini, data hasil uji kepekaan memperlihatkan PHMB memberikan kepekaan $96,5 \%$ terhadap 10 jenis kuman (55 sampel penelitian); kepekaan 83,3\% terhadap kuman Citrobacter diversus; dan kepekaan $60 \%$ terhadap kuman Proteus mirabilis sedangkan $\mathrm{NaCl} 20 \%$ gel sebagai kontrol menunjukkan hasil $98,3 \%$ resistensi ditandai dengan tidak terbentuknya zona hambat kuman pada uji kepekaan yang dilakukan.

Berdasarkan hasil uji statistik didapatkan perbedaan proporsi sensitivitas PHMB yang bermakna $(P<0,05)$ pada Proteus mirabilis, Pseudomonas aeroginosa, Citrobacter diversus, Enterobacter aerogenes, Klebsiela pneumonia, Eschericia coli, Proteus vulgaris (bakteri Gram negatif) serta Staphylococcus aureus, Staphylococcus epidermidis, dan Streptococcus sp. (bakteri Gram positif). Hasil ini sejalan dengan penelitian sebelumnya oleh Kaehn yang menyatakan bahwa PHMB mempunyai spektrum luas untuk bakteri Gram negatif dan Gram positif. ${ }^{14}$ Penelitian ini juga selaras dengan penelitian Cazzaniga et al. yang melaporkan bahwa PHMB merupakan antimikroba yang efektif. ${ }^{19}$ Hasil penelitian oleh Lee menyatakan bahwa PHMB efektif menghambat pertumbuhan kuman Staphylococcus aureus, Pseudomonas aeroginosa, Proteus mirabilis, Klebsiela pneumonia, dan Eschericia coli. ${ }^{20}$
Efektivitas PHMB pada penelitian ini sesuai dengan kajian kerja PHMB sebagai bakterisidal dengan sifat basanya berikatan dengan fosfat bermuatan negatif pada membran fosfolipid bakteri, menghancurkan membran luar dan dalam dari dinding sel bakteri melalui gangguan permeabilitas, dan mengeluarkan sitoplasma sel bakteri dengan cara osmosis. ${ }^{13,14}$

Hasil uji statistik mendapatkan perbedaan tidak bermakna dari proporsi kepekaan terhadap $\mathrm{NaCl} 20 \%$ gel $(P>0,05)$ dari Proteus mirabilis, Pseudomonas aeroginosa, Citrobacter diversus, Enterobacter aerogenes, Klebsiela pneumonia, Eschericia coli, Proteus vulgaris (bakteri Gram negatif) serta Staphylococcus aureus, Staphylococcus epidermidis, dan Streptococcus sp. (bakteri Gram positif). Hasil penelitian ini tidak sejalan dengan penelitian sebelumnya yang dilakukan oleh Kiura et al. ${ }^{15}$ yang menyimpulkan bahwa $\mathrm{NaCl}$ konsentrasi tinggi mempunyai efek bakterisidal yang baik dan dapat dijelaskan dengan mengkaji kembali sifat kerja $\mathrm{NaCl}$ dalam menghancurkan bakteri. Pada perbandingan efek bakterisidal antara $\mathrm{NaCl}$ konsentrasi rendah dan konsentrasi tinggi dijelaskan bahwa $\mathrm{NaCl}$ dalam bentuk cairan mempunyai sifat mendilusi dan menghancurkan membran luar dari bakteri ${ }^{15,16}$ Pada penelitian ini, $\mathrm{NaCl}$ yang dipakai, meskipun mempunyai konsentrasi yang tinggi (20\%), namun bentuk yang tersedia ialah gel sehingga mekanisme kerja $\mathrm{NaCl}$ dalam bentuk cair yang dapat mendilusi membran luar bakteri, tidak bisa dicapai dalam penelitian ini. Klorin bebas, seperti $\mathrm{HCLO}, \mathrm{Cl}_{2}$, dan $\mathrm{Cl}^{-}$yang merupakan hasil elektrolisis dari $\mathrm{NaCl}$ tidak bisa berinteraksi dengan enzim bakteri atau menghancurkan periplasma dan membran dalam sehingga sitoplasma tidak dapat keluar dari sel bakteri, dan tidak berakhir dengan kematian bakteri.

\section{SIMPULAN}

Dari hasil penelitian terhadap pasien ulkus diabetik terinfeksi didapatkan kuman Gram negatif dengan persentase tertinggi, 
dengan hasil kultur pus memperlihatkan pola kuman terbanyak ialah Proteus mirabilis. Hasil uji sensitivitas pola kuman mendapatkan polyhexamethylene biquanide (PHMB) gel memperlihatkan sensitivitas $100 \%$ dari 9 jenis kuman dan sensitivitas $50 \%$ dari kuman Proteus vulgaris, sedangkan $\mathrm{NaCl}$ gel memperlihatkan resistensi dari seluruh pola kuman.

\section{DAFTAR PUSTAKA}

1. Ronald C, Peter T. Epidemiology of type 2 diabetes. In: Richard $\mathrm{H}$, Clive C, Allan F, Barry G, editors. Textbook of Diabetes (4th ed). Oxford: Wiley Blackwell Ltd, 2010; p. 31-44.

2. Shadi C, Bahman P. Epidemiology. In: Leonid P, editor. Principles of Diabetes Mellitus (2nd ed). New York: Springer, 2010; p. 117-28.

3. Suyono S. Kecenderungan peningkatan jumlah penyandang diabetes. In: Sugondo S, Soewondo P, Subekti I, editors. Penatalaksanaan Diabetes Mellitus Terpadu (6th ed). Jakarta: Penerbi FKUI, 2011; p. 3-10.

4. Tentolouris N. Introduction. In: Nicholas K, Eleftherios D, Panagiotis T, Nicholas T, editors. Atlas of the Diabetic Foot. Oxford: John Wiley \& Sons Inc, 2010; p. 1-10.

5. Boulton JM. Foot problems in patients with diabetes. In: Richard I, Clive C, Allan F, Barry J, editors. Textbook of Diabetes $\left(4^{\text {th }}\right.$ ed). Oxford: Blackwell Publishing, 2010; p. 727-43.

6. Hastuti R. Faktor-faktor risiko ulkus diabetika pada penderita diabetes mellitus [Disertasi]. Semarang: Universitas Diponegoro; 2008.

7. Cokram CS Nelson L. Diabetes and infection. In: Richard H, Clive C, Allan F, Barry $\mathrm{G}$, editors. Textbook of Diabetes $\left(4^{\text {th }}\right.$ ed). Oxford: Wiley- Blackwell, 2010; p. 835-55.

8. Tsapogas P. Infection. In: Nicholas K, Eleftherios D, Panagiotis T, Nicholas T, editors. Atlas of the Diabetic Foot. Oxford: John Wiley \& Sons Inc, 2010; p. 1-10.

9. Karchmer AW. Microbiology and treatment of diabetic foot infections. In: Aristidis V, John M, Frank W, editors. The Diabetic Foot Medical and Surgical
Management. New Jersey: Humana Press Inc, 2002.

10. Butcher M. PHMB: an effective antimicrobial in wound bioburden managemen. BJN. 2012 (tissue viability supplement);21(12):S16-S21.

11. Moses S. Saline gauze dressing. Family Practice Notebook. Boston: LLC, 2008.

12. Clayton W, Elasy TA Review of the pathophysology, classification, and treatment of foot ulcers in diabetic patients. Clin Diabetes. 2009;27(2):528.

13. de Paula GF, Netto GI, Mattoso LHC. Physical and chemical characterization of polyhexamethylene biguanide hydrochlorida. Polymers. 2011;3:92841.

14. Kaehn K. Polyhexamethylene biguanide hydrochlorida: A safe and highly effective biocide. Skin Pharmacol Physiol. 2010;23(Suppl.1):7-16.

15. Kiura H, Sano K, Morimatsu S, Nakano T, Morita C, Yamaguchi $M$, et al. Bactericidal activity of electrolyzed acid water from solution containing sodium chlorida at low concentration, in comparison with that a high concentration. J Microbiol methods. 2002;49:285-93.

16. Yokoyama I, Nakano T, Morita C, Aria Y, Hiyama $T$, Aoki $H$, et al. Establishment of gold standard for electrolyzed sodium chloride solution in disinfection. Bulletin of the Osaka medical college. 2007;53:11-9.

17. Decroli E, Karimi J, Manaf A, Syahbuddin S. Profil ulkus diabetik pada penderita rawat inap di Bagian Penyakit Dalam RSUP Dr. M. Djamil Padang. Maj Kedokt Indon. 2008;581.

18. Maginstar C, Sapan H, Sumangkut R, Ngantung $\mathbf{J}$, Waworuntu $\mathbf{L}$, Lolombulan J. Uji sensitivitas cuka $5 \%$, hidrogan peroksida $3 \%$ dan asam perasetik terhadap pola kuman penderita ulkus diabetik di RSUP Prof. Dr. R. D. Kandou Manado. Manado: FK Unsrat 2013; p. 31-46.

19. Cazzaniaga A, Serralta V, Davis S, Orr R, Eaglstein W, Mertz PM. The effect of an antimicrobial gauze dressing impregnated with 0.2 percent polyhexamethylene biguanide as a barrier to prevent Pseudomonas 
44 Jurnal Biomedik (JBM), Volume 9, Nomor 1, Maret 2017, hlm. 38-44

aeruginosa woud invasion.Wounds. 2002;14(5):169-76.

20. Mulder GD, Cavorsi JP, Lee D.

Polyhexamethylene

biguanide
(PHMB): an addendum to current topical antimicrobials. Wounds. 2007; 19(7):173-82. 